\title{
Use of the Femtosecond Laser for Cataract Surgery with Intraocular Lens Implantation
}

\author{
Tatsuya Mimura $^{1 *}$ and Kenichiro Yamazaki
}

${ }^{1}$ Department of Ophthalmology, University of Tokyo Graduate School of Medicine, Tokyo, Japan

${ }^{2}$ Omiya Nanasato Eye Institute, Saitama, Japan

\begin{abstract}
Femtosecond laser technology offers a promising approach to minimally invasive corneal surgery. Recently, femtosecond laser-assisted cataract surgery has been approved by the FDA. Femtosecond laser systems can create more precise and reproducible surgical incisions under computer control than with the conventional manual technique. Femtosecond laser-assisted cataract surgery may become a standard procedure for cataract surgery with intraocular lens implantation.
\end{abstract}

Cataract is one of the major causes of preventable blindness in both developing and industrialized countries. Today most cataracts can be treated safely by modern surgical techniques involving phacoemulsification of the lens and intraocular lens (IOL) implantation. The management of cataract has changed considerably over the last few years with various improvements in surgical techniques, especially adoption of the femtosecond laser. This laser was first introduced for flap creation during laser in-situ keratomileusis (LASIK) [1-6]. Since then, the femtosecond laser has been used in a variety of procedures for corneal surgery, including predissection of corneal grafts for penetrating keratoplasty [7], anterior and posterior lamellar keratoplasty [8-12], and Descemet's stripping automated endothelial keratoplasty. It has also been used for refractive surgery [13], including LASIK, limbal relaxing incisions, intrastromal ring segment implantation [14], and correction of presbyopia. Most recently, use of the femtosecond laser has been expanded to include cataract surgery [15].

The name femtosecond laser indicates the short duration of its laser pulses ( 1 femtosecond ( $\mathrm{fs})=1 \times 10^{-15}$ seconds). Other lasers used for ocular surgery, such as the argon (photocoagulation), excimer (photo ablation), and ND: YAG (photo disruption) lasers have a longer pulse time of $10^{-9}$ seconds. Several companies have developed femtosecond laser units for cataract surgery. These include the LenSx (Alcon, Fort Worth, TX), Optimedica Catalyst (Optimedica Corporation, Sant Clara, CA, USA), Technolas Workstation and IntraCor (Technolas Perfect Vision GmbH, Munich, Germany), and LensAR Laser System (LensAR Inc., Winter Park, FL). The femtosecond laser first received FDA approval for use in lamellar corneal surgery and additional approval for femtosecond laser-assisted cataract surgery was granted in 2010 .

Femtosecond laser systems can create precise and reproducible surgical incisions under computer control. The chief benefit of using a femtosecond laser for cataract surgery is that it replaces manual incision with a dedicated knife or forceps for creation of the initial corneal incisions, capsulotomy, and initial lens fragmentation. Successful intraocular use of the femtosecond laser for lens fiber disruption [16], treatment of presbyopia [17], and accommodation surgery [18] has been achieved in animal models. The first surgeon to report the performance of femtosecond laser-assisted cataract surgery in humans was Nagy in 2009 [19]. Since this initial report, many further reports and reviews of femtosecond laser-assisted cataract surgery have been published [20-41]. The first advantage of femtosecond-assisted cataract surgery is more precise capsulorrhexis and phacoemulsification at a lower power than with the conventional manual technique $[19,41]$. For accurate centration and fixation of advanced IOLs, including toric, multifocal, and accommodating IOLs, use of the femtosecond laser to achieve accurate capsulorhexis may be an effective option. A second advantage is that the femtosecond laser creates precise corneal incisions. Three-dimensional computer control of the corneal incision using a femtosecond laser may reduce the risk of endophthalmitis associated with manual self-sealing clear corneal incisions. The third advantage is that the femtosecond laser allows precise placement of limbal relaxing incisions, which are effective for reducing astigmatism after cataract surgery. The fourth advantage is that femtosecond laser light is not absorbed by the surrounding tissues, including the cornea, resulting in no risk of corneal damage.

Despite all these positive aspects, the laser units are still relatively large and under development. Additionally, femtosecond laser machines equipped with a rotating Scheimpflug camera or optical coherence tomography incur additional costs for spare parts and annual maintenance, and are considerably more expensive compared with the current standard method of cataract surgery. Further investigation of postoperative complications such as endophthalmitis is also necessary. If these issues can be solved, femtosecond laser-assisted cataract surgery may become a standard procedure for treating cataract in the near future. Development of a femtosecond laser combined with a phacoemulsification unit is also expected.

\section{References}

1. Ratkay-Traub I, Juhasz T, Horvath C, Suarez C, Kiss K, et al. (2001) Ultrashort pulse (femtosecond) laser surgery: initial use in LASIK flap creation. Ophthalmol Clin North Am 14: 347-355.

2. Nordan LT, Slade SG, Baker RN, Suarez C, Juhasz T, et al. (2003) Femtosecond laser flap creation for laser in situ keratomileusis: six-month follow-up of initial U.S. clinical series. J Refract Surg 19: 8-14.

3. Kezirian GM, Stonecipher KG (2004) Comparison of the IntraLase femtosecond laser and mechanical keratomes for laser in situ keratomileusis. J Cataract Refract Surg 30: 804-811.

4. Salomao MQ, Wilson SE (2010) Femtosecond laser in laser in situ keratomileusis. J Cataract Refract Surg 36: 1024-1032.

*Corresponding author: Tatsuya Mimura, MD, Ph.D, Department of Ophthalmology, University of Tokyo Graduate School of Medicine, 7-3-1 Hongo, Bunkyo-ku, Tokyo, 113-8655 Japan, Tel: +81 35800-5108; Fax: +81 33817-0798; E-mail: mimurat-tky@umin.ac.jp

Received October 10, 2012; Accepted October 12, 2012; Published October 15 2012

Citation: Mimura T, Yamazaki K (2012) Use of the Femtosecond Laser for Cataract Surgery with Intraocular Lens Implantation. J Transplant Technol Res 2:e116. doi:10.4172/2161-0991.1000e116

Copyright: @ 2012 Mimura T, et al. This is an open-access article distributed unde the terms of the Creative Commons Attribution License, which permits unrestricted use, distribution, and reproduction in any medium, provided the original author and source are credited. 
Citation: Mimura T, Yamazaki K (2012) Use of the Femtosecond Laser for Cataract Surgery with Intraocular Lens Implantation. J Transplant Technol Res 2:e116. doi:10.4172/2161-0991.1000e116

Page 2 of 2

5. Gil-Cazorla R, Teus MA, de Benito-Llopis L, Mikropoulos DG (2011) Femtosecond laser vs mechanical microkeratome for hyperopic laser in situ keratomileusis. Am J Ophthalmol 152: 16-21.

6. Sutton G, Hodge C (2008) Accuracy and precision of LASIK flap thickness using the IntraLase femtosecond laser in 1000 consecutive cases. J Refract Surg 24: 802-806.

7. Ghanem RC, Azar DT (2006) Femtosecond-laser arcuate wedge-shaped resection to correct high residual astigmatism after penetrating keratoplasty. J Cataract Refract Surg 32: 1415-1419.

8. Harissi-Dagher M, Azar DT (2008) Femtosecond laser astigmatic keratotomy for postkeratoplasty astigmatism. Can J Ophthalmol 43: 367-369.

9. Nubile M, Carpineto P, Lanzini M, Calienno R, Agnifili L, et al. (2009) Femtosecond laser arcuate keratotomy for the correction of high astigmatism after keratoplasty. Ophthalmology 116: 1083-1092.

10. Price FW Jr, Price MO, Grandin JC, Kwon R (2009) Deep anterior lamellar keratoplasty with femtosecond-laser zigzag incisions. J Cataract Refract Surg 35: 804-808

11. Prakash G, Jacob S, Ashok Kumar D, Narsimhan S, Agarwal A, et al. (2009) Femtosecond-assisted keratoplasty with fibrin glue-assisted sutureless posterior chamber lens implantation: new triple procedure. J Cataract Refract Surg 35: 973-979.

12. Buzzonetti L, Laborante A, Petrocelli G (2011) Refractive outcome of keratoconus treated by combined femtosecond laser and big-bubble deep anterior lamellar keratoplasty. J Refract Surg 27: 189 -194.

13. Kim P, Sutton GL, Rootman DS (2011) Applications of the femtosecond laser in corneal refractive surgery. Curr Opin Ophthalmol 22: 238-244.

14. Ertan A, Kamboruglu G, Akgün U (2007) Comparison of outcomes of 2 channe sizes for intrastromal ring segment implantation with a femtosecond laser in eyes with keratoconus. J Cataract Refract Surg 33: 648-653.

15. Farid M, Steinert RF (2010) Femtosecond laser-assisted corneal surgery. Curr Opin Ophthalmol 21: 288-292.

16. Krueger RR, Kuszak J, Lubatschowski H, Myers RI, Ripken T, et al. (2005) First safety study of femtosecond laser photodisruption in animal lenses: tissue morphology and cataractogenesis. J Cataract Refract Surg 31: 2386-2394.

17. Gerten G, Ripken T, Breitenfeld P, Krueger RR, Kermani O, et al. (2007) In vitro and in vivo investigations on the treatment of presbyopia using femtosecond lasers. Ophthalmologe 104: 40-46.

18. Schumacher S, Fromm M, Oberheide U, Gerten G, Wegener A, et al. (2008) In vivo application and imaging of intralenticular femtosecond laser pulses for the restoration of accommodation. J Refract Surg 24: 991-995.

19. Nagy Z, Takacs A, Filkorn T, Sarayba M (2009) Initial clinical evaluation of an intraocular femtosecond laser in cataract surgery. J Refract Surg 25: 10531060.

20. He L, Sheehy K, Culbertson W (2011) Femtosecond laser-assisted cataract surgery. Curr Opin Ophthalmol 22: 43-52.

21. Mamalis N (2011) Femtosecond laser: the future of cataract surgery? J Cataract Refract Surg 37: 1177-1178.

22. Nagy ZZ, Kránitz K, Takacs Al, Miháltz K, Kovács I, et al. (2011) Comparison of intraocular lens decentration parameters after femtosecond and manual capsulotomies. J Refract Surg 27: 564-569.

23. Kránitz K, Takacs A, Miháltz K, Kovács I, Knorz MC, et al. (2011) Femtosecond laser capsulotomy and manual continuous curvilinear capsulorrhexis parameters and their effects on intraocular lens centration. J Refract Surg 27 558-563.

24. Ackermann R, Kunert KS, Kammel R, Bischoff S, Bühren SC, et al. (2011) Femtosecond laser treatment of the crystalline lens: a 1-year study of possible cataractogenesis in minipigs. Graefes Arch Clin Exp Ophthalmol 249: 15671573.

25. Ecsedy M, Miháltz K, Kovács I, Takács A, Filkorn T, et al. (2011) Effect of femtosecond laser cataract surgery on the macula. J Refract Surg 27: 717-722.

26. Roberts TV, Sutton G, Lawless MA, Jindal-Bali S, Hodge C (2011) Capsular block syndrome associated with femtosecond laser-assisted cataract surgery. J Cataract Refract Surg 37: 2068-2070.
27. Miháltz K, Knorz MC, Alió JL, Takács Al, Kránitz K, et al. (2011) Interna aberrations and optical quality after femtosecond laser anterior capsulotomy in cataract surgery. J Refract Surg 27: 711-716.

28. Uy HS, Edwards K, Curtis N (2012) Femtosecond phacoemulsification: the business and the medicine. Curr Opin Ophthalmol 23: 33-39.

29. Moshirfar M, Churgin DS, Hsu M (2011) Femtosecond laser-assisted cataract surgery: a current review. Middle East Afr J Ophthalmol 18: 285-291.

30. Bali SJ, Hodge C, Lawless M, Roberts TV, Sutton G (2012) Early experience with the femtosecond laser for cataract surgery. Ophthalmology 119: 891-899.

31. Yeoh R (2012) Hydrorupture of the posterior capsule in femtosecond-lase cataract surgery. J Cataract Refract Surg 38: 730.

32. Yu YH, Yao K (2012) New applications of femtosecond laser in cataract surgery. Yan Ke Xue Bao 27: 50-56

33. Feizi S (2011) Femtosecond laser cataract surgery. J Ophthalmic Vis Res 6 : 151.

34. Takács Al, Kovács I, Miháltz K, Filkorn T, Knorz MC, et al. (2012) Centra corneal volume and endothelial cell count following femtosecond laser-assisted refractive cataract surgery compared to conventional phacoemulsification. J Refract Surg 28: 387-391.

35. Bali SJ, Hodge C, Chen S, Sutton G (2012) Femtosecond laser assisted cataract surgery in phacovitrectomy. Graefes Arch Clin Exp Ophthalmol 250: 1549-1551.

36. Filkorn T, Kovács I, Takács A, Horváth E, Knorz MC, et al. (2012) Comparison of IOL power calculation and refractive outcome after laser refractive cataract surgery with a femtosecond laser versus conventional phacoemulsification. $J$ Refract Surg 28: 540-544.

37. Roberts TV, Lawless M, Chan CC, Jacobs M, Ng D, et al. (2012) Femtosecond laser cataract surgery: technology and clinical practice. Clin Experiment Ophthalmol

38. Szigeti A, Kránitz K, Takacs Al, Miháltz K, Knorz MC, et al. (2012) Comparison of long-term visual outcome and IOL position with a single-optic accommodating IOL After 5.5- or 6.0-mm Femtosecond laser capsulotomy. J Refract Surg 28: 609-613.

39. Conrad-Hengerer I, Hengerer FH, Schultz T, Dick HB (2012) Effect of femtosecond laser fragmentation of the nucleus with different softening grid sizes on effective phaco time in cataract surgery. J Cataract Refract Surg.

40. Palanker DV, Blumenkranz MS, Andersen D, Wiltberger M, Marcellino G, et al. (2010) Femtosecond laser-assisted cataract surgery with integrated optical coherence tomography. Sci Transl Med 2: 58 ra85

41. Friedman NJ, Palanker DV, Schuele G, Andersen D, Marcellino G, et al. (2011) Femtosecond laser capsulotomy. J Cataract Refract Surg 37: 1189-1198. 